\title{
Editorial
}

\section{The Reproductive Health and Rights Agenda Under Attack}

The reproductive rights and health agenda negotiated through agreements made at the International Conference on Population and Development (ICPD), in 1994 and at the five-year review in 1999, is undeniably under attack in the uneasy world of 2003. There are a number of common explanations offered for why. The first is that there is just not enough money. Stringent economic policies imposed by the global economic order are not concurrent with the recommendations of the ICPD and other instruments that aim to put in place a pro-people health policy. Then there are issues around governance. Wavering democratic systems in many countries fail to provide the robust institutions to ensure promises are kept and local needs heard and respected. Then there is the concern about the growing uncontrollability of the unwieldy globalized world. The commodification of sexuality - in advertising, on the Internet, the trafficking in women and girls, the spread of HIV and AIDS - are among the disturbing features highlighted by the press and others that explain the undermining of the reproductive health and rights agenda.

However, as many of the articles in this journal reveal, the situation is in fact far more complex. Certainly no one can deny that having enough money, good governance, and a more democratic and just global order that respects women's rights are all necessary. And in this sense, very few people would speak out against good public health systems, the end of trafficking of girls and women, universal education and better governance systems. But when it comes to committed money, to the priorities of good governance and how far women's rights can be exercised, many would start to talk about the need for priorities. Here the 'real' issues emerge: the need to support trade, resolve the financial crisis, stop wars, prevent ethnic conflict, end environmental degradation and cope with climate change. In this discourse, women's reproductive rights and health diminish into the periphery - or at best become one of the, eventual, benefits of development. 
As such, the problem is much more deep-seated than the ICPD process suggests. Is it enough to learn how to respond to official development agendas that mention women, reproductive rights and health in a few paragraphs, if at all? Would better, more convincing advocacy tools, more timely strategies, better lobbying, more appealing arguments for legal reform, be able to tackle completely such rejection of the reproductive rights and health agenda?

The answer from the articles is clearly no. While lobbying and advocacy activities are certainly necessary and are engaging many good people, the range of the problems demands that reproductive rights and health issues are not sidelined in development debates, policy and action. This means it is important to recognize that they are sidelined not just because of lack of money, inadequate governance and rampant globalization. Reproductive rights and health, particularly when they openly encompass sexual health, go right to the heart of profound economic, social and political inequalities. As the Women's International Coalition for Economic Justice suggests, the dismantling of the reproductive rights agenda is part and parcel of today's current fundamentalisms - the 'fundamentalism' of the market and the ethnic and religious fundamentalisms that are taking advantage of the rapidly increasing social fractures and insecurities that characterize today's majority world living in poverty. Both of these fundamentalisms are devastating to women, who suffer not only from the loss of livelihoods and economic security, but also from the loss of control over their life choices and their bodies.

As Sonia Corrêa argues in her contribution, these two types of fundamentalism are intertwined. The insecurities created by economic globalization open the way for conservative religious or ethnic 'fundamentalist' movements and groups to gain a hold in both the North and South. In the South these forces feed on insecurities created by the loss of livelihoods in urban and rural areas evoking explicitly anti-women sentiments as a way to provide cultural identity. They are often also the strongest voices against globalization, because for them globalization means a loss of political, economic and cultural control. In the the loss of self in the mire of consumerism has led to a rise in fundamentalist right-wing groups that are sexist as well as racist and xenophobic.

As the articles from Indonesia, Thailand, New Zealand, The Pacific, India and Nepal attest, internationally and nationally the political, economic and cultural disruption of these fundamentalisms are dismantling women's hard-won rights to define a sexual rights and reproductive health agenda, to express their sexual and reproductive rights, and to have access to resources that assure life choices leading to reproductive health and well-being. As Yvonne Underhill-Sem shows, corporate globalization and fundamentalisms are leaving deep marks on women's reproductive and productive bodies in a shifting 'body politics' that commodifies and controls women's bodies.

It is a real concern, stated in the open letter in support of the ICPD, that within the UN processes conservative states are working to reverse the commitments made at world conferences, particularly regarding issues of reproductive rights, social justice and equality. The five-year review processes revealed the extent to which fundamentalist forces fought to reverse hard-won gains on women's rights and social development.

In this context, the call for women's reproductive rights and health goes far beyond a technical issue. It becomes a strong political challenge to family, health, judicial, educational, economic and cultural institutions. While confronting the huge problems to be faced, what the articles also show is that many women's groups are fighting back to stop the attack on the reproductive rights and health agenda. The articles show women's courage to take the solution in their own hands - women's health groups providing training for 300 volunteer midwives in isolated areas of Papua New Guinea, news services focusing on women's achievements to combat HIV and AIDS, women in marginalized war-torn areas in Uganda and Palestine finding ways to help heal war-torn bodies and minds.

However a transformation of deep-seated gender bias, dominating economic forces and patriarchal cultural systems is not something that happens quickly, especially when the biases are deeply embedded in powerful political and knowledge domains. 
We hope that this issue consolidates and encourages ways forward to bring about that transformation inspired by actions, analysis and advocacy campaigns that aim to reverse economic, religious and ethnic fundamentalism. As the numerous organizations described in Window on the World suggests, this requires a multiple strategic approach built on sophisticated networking and alliance building. Such a process will channel the knowledge, experience and vision of women's groups working on reproductive rights and health within and across communities and societies to macro-level changes and a transformation of political rules of the game.

There are some major questions ahead if we are to cultivate new political alliances that will tackle at the core the violations of women's rights, bodies and freedom. Can different groups supporting women's reproductive rights join immigrant support groups, anti-GM-crop groups, anti-racist movements, disabled rights groups, opponents of privatization of public services and groups defending their commons in a new type of alliance and politics? The reproductive rights and health agenda can no longer be understood as a narrow technical issue but as an agenda that must respond to the challenge that the fundamentalisms of the 'free market' and ethnic and religious groups are posing. Women's reproductive rights and health is not only a key issue in itself, but is also critical to the achievement of economic and social justice. Especially given the threats to the UN process that has to date galvanized the reproductive rights and health agenda, such new political alliances for women's rights, reproductive and sexual health have to be forged in order to navigate the increasingly difficult and complex global conditions.

The journal issue will be published on 28 May 2003, the 16th International Day of Action for Women's Health, in support of the Women's Global Network for Reproductive Rights and the People's Health Assembly's Call for Action 2003. By launching the issue on an international day of action, we hope to contribute to the work of people's health movements and women's groups and organizations in ensuring primary health care and sexual and reproductive rights for all.

development is abstracted in Academic Search, Cab Abstracts, Communication Abstracts, Environmental Abstracts, GEOBASE, Geo Abstracts: Human Geography, HRI Reporter, International Development Abstracts, International Labour Documentation, International Political Science Abstracts, Social Services Abstracts, Sociofile and Sociological Abstracts; and is indexed in Business Source, CSA Political Science \& Government, Econlit, Environmental Abstracts, Environmental Sciences \& Population Management, Human Population \& Environment, International Bibliography of the Social Sciences, Journal of Economic Literature, MasterFILE fullNET, OCLC Public Affairs Information Service. 